See discussions, stats, and author profiles for this publication at: https://www.researchgate.net/publication/333709373

\title{
Effects of plant traits and their divergence on runoff and sediment retention in herbaceous vegetation
}

Article in Plant and Soil · August 2019

DOI: 10.1007//11104-019-04142-6

\section{CITATIONS}

10

4 authors, including:

Léa Kervroëdan

Institut Polytechnique UniLaSalle

11 PUBLICATIONS 50 CITATIONS

SEE PROFILE

(2) Michel-Pierre Faucon

Institut Polytechnique UniLaSalle

125 PUBLICATIONS 1,902 CITATIONS

SEE PROFILE

\section{READS}

308

Institut Polytechnique UniLaSalle

26 PUBLICATIONS 234 CITATIONS

SEE PROFILE

Some of the authors of this publication are also working on these related projects:

Project $\quad$ Long-term silicon dynamics in terrestrial ecosystems: insights from long-term chronosequences View project

Project A functional trait-based approach of ecological and agroecological engineering View project 


\section{Effects of plant traits and their divergence on runoff and sediment}

\section{retention in herbaceous vegetation}

4

5

6 Léa Kervroëdan* ${ }^{\text {ab }}$, Romain Armand ${ }^{a}$, Mathieu Saunier ${ }^{\mathrm{b}}$, Michel-Pierre Faucon ${ }^{\mathrm{a}}$

8 aAGHYLE (SFR Condorcet FR CNRS 3417), UniLaSalle, 19 Rue Pierre Waguet, 60026

9 Beauvais, France

bAREAS, 2 avenue Foch, 76460 St Valéry en Caux, France

*Corresponding author: UniLaSalle, 19 Rue Pierre Waguet, 60026 Beauvais, France. E-mail address: lea.kervroedan@unilasalle.fr

Key-words

16 Aboveground functional traits; Plant-soil-runoff interactions; Sediment transport; Sediment trapping and deposition; Soil erosion control

20 Abstract

21 Aims

22 Plant species diversity impacts ecosystem processes, but its effects on runoff and soil erosion are not fully understood. Herbaceous vegetation control concentrated runoff and soil erosion through the increase of hydraulic roughness which leads to sediment retention. This study aims 
to investigate the effect of aboveground traits and their divergence (i.e., stem diameter and density, and leaf area and density) on hydraulic roughness and sediment retention in plant communities.

Methods

Runoff experimentations were performed, using a sediment input, on three mono-specific and one multi-specific conditions composed of plant species with contrasting traits furthering hydraulic roughness and sediment retention.

\section{Results}

No effect of trait diversity was found on the hydraulic roughness and sediment retention; which would be explained by the absence of an optimal space use by the traits involved in the increase of the hydraulic roughness. The dominant effect of the community-weighted traits in the plant community drives the effects of the vegetation on the hydraulic roughness and sediment retention.

\section{Conclusion}

This absence of positive effects of the trait diversity on hydraulic roughness and sediment retention constitutes an important knowledge to model runoff and soil erosion processes and to design herbaceous infrastructures for soil erosion control.

(1)

\section{Introduction}

Soil-plant interactions play a key role in the reduction of runoff and soil erosion (Styczen and Morgan 1995). The effects of plant functional traits (i.e., 'morpho-physio-phenological traits which indirectly impact fitness via their effects on growth, reproduction and survival' (Violle et al. 2007)) in herbaceous vegetation have been studied on different processes generating and 
Bédécarrats 2007; Burylo et al. 2012; Stokes et al. 2014; Liu et al. 2016; Mekonnen et al. 2016).

In vegetation patches, notably under temperate climates, concentrated runoff and soil erosion

are mainly controlled by the hydraulic roughness of herbaceous vegetation (i.e. frictional resistance of the vegetation in contact with the flow) which induces sediment retention by slowing the flow velocity (Meyer et al. 1995; Akram et al. 2014). More the flow velocity will be reduced, more the quantity of sediments which will be retained by the vegetation will comprise a wider variety of particle sizes, and especially smaller particles (Haan et al. 1994; Syversen and Borch 2005). This indirect effect of the plant traits on the fractions of sediment particles retained constitutes an important feature to understand the vegetation effects on soil erosion, notably regarding the environmental consequences as the smaller sediment particles are the most impacting ones regarding pollutant dispersion and water quality degradation (Syversen and Borch 2005; Liu et al. 2008; Lambrechts et al. 2014). The effects of functional traits on hydraulic roughness and sediment retention have been studied over the past decades, showing the effects of aboveground biomass, projected stem area (i.e. stem area towards the flow direction), stem density and diameter as well as leaf area and density (Burylo et al. 2012; Zhu et al. 2015; Mekonnen et al. 2016; Kervroëdan et al. 2018). Some of these traits are found negatively correlated (e.g. leaf area and density), implying that trait diversity and divergence could have a better impact on hydraulic roughness and sediment retention by exerting complementary effects of the traits (Kervroëdan et al. 2018). Positive effects of the trait aggregation, due to trait divergence - or functional diversity - are driven by the complementarity of the traits which leads to a better space occupation inducing greater effects of the community structure and distribution on soil erosion reduction (Zhu et al. 2015). On the other hand, when no effects of the trait diversity are observed, it is the community-weighted traits (i.e. the mean of the trait values in the plant community) that are leading the effects on 
the hydraulic roughness and sediment retention (Erktan et al. 2013; Zhu et al. 2015). As for several other ecosystem processes, plant species diversity integrating contrasting plant functional traits can influence the processes involved in soil erosion (Naeem et al. 1994; Tilman 2001a; Martin et al. 2010; Zhu et al. 2015). The mechanisms driving the effects of plant species diversity on ecosystem processes can follow two non-exclusive hypotheses (Loreau 2000; Garnier et al. 2016). The selection hypothesis stipulates that one or more dominant species in the community would increase the overall productivity and efficiency of the community. On the other hand, the complementarity hypothesis specifies that plant species diversity effects on ecosystem processes result from a more complete space and resource uses by the trait divergence composing the plant community (Loreau and Hector 2001; Fargione et al. 2007). The relationships between plant trait diversity and soil erosion processes have been studied, mostly focussing on the effects of non-herbaceous plant roots on soil stabilisation and vegetation patch pattern impact on erosion rates (Gyssels et al. 2005; Bautista et al. 2007; Pohl et al. 2009; Martin et al. 2010; Berendse et al. 2015; Hou et al. 2016). However, the effects of trait diversity on sediment retention are not well known and can be contrasting (Martin et al. 2010; Erktan et al. 2013; Zhu et al. 2015; Hou et al. 2016). Studies focussing on the effects of functional diversity on sediment retention and erosion rates showed controversial effects on the functional diversity (i.e., 'the value, range, and relative abundance of plant functional traits in a given ecosystem' (Tilman 2001b; Díaz et al. 2007)) (Erktan et al. 2013; Zhu et al. 2015). Influenced by neighbouring, the interspecific differences in functional traits among diverse plant communities have been found to impact positively soil erosion reduction (Zhu et al. 2015). These debated results stress the need to deepen the knowledge on the effects of the trait diversity in herbaceous vegetation on concentrated runoff and soil erosion to increase hydraulic roughness and sediment retention. 

on the hydraulic roughness and sediment retention by characterising the quantity of retained sediments and their sizes. We hypothesised that the aggregation of contrasting traits involved in the increase of the hydraulic roughness would induce a better aboveground space use and a better sediment retention. The traits and their divergence, which would have a greater effect on

103 the hydraulic roughness, would lead to a wider variety of the size of the retained sediments by 104 the multi-specific plant communities.

105

106

\section{Materials and methods}

This trait-based plant-soil study aimed to examine the effects of the traits and their divergence

\section{Materials and methods}

\section{Plant material}

Three herbaceous species presenting contrasting aboveground morphological traits furthering the hydraulic roughness were selected from a list of 76 potential candidate species of indigenous plants from north-west Europe. This list was obtained by applying six criteria to the 3500 spermatophyte species of north-west Europe (Lambinon et al. 2012) based on the identified functional types influencing runoff and soil erosion in this phytogeographical territory (Kervroëdan et al. 2018): (1) the Raunkiaer's life-form categories “herbaceous chamaephytes”, "hemicryptophytes" and "geophytes" which select perennial herbaceous species with an effective soil cover all year; (2) the presence of biomass during winter, when soil erosion is observed at its highest in north-west Europe (Boardman and Poesen 2006), either dry (i.e., noncaespitose hemicryptophytes and geophytes) or fresh (i.e., herbaceous chamaephytes and caespitose hemicryptophytes); (3) the presence of stolon or rhizomes which ensure a lateral spreading growth pattern forming a homogenous cover and burying tolerance towards sediment deposition; (4) a vegetative height $\geq 20 \mathrm{~cm}$ to avoid any submergence of the vegetation by the water flow and ensure the efficiency towards concentrated flows (Dillaha et al. 1989), as the 
123 water maximal level is $20 \mathrm{~cm}$ in north-west European catchments; (5) a broad ecological niche

124 which guarantee the plants development within a wide gradient of soil conditions and (6) the

125 non-invasiveness of the plants which select non-weed species and avoid the plant spreading

126 into agricultural fields.

127 To restrict the competition for light, the species were chosen considering their vegetative height

128 range with a minimal height comprised between 40 and $70 \mathrm{~cm}$. The species Carex pendula

129 Huds., Tanacetum vulgare L. and Festuca arundinacea Schreb. were tested under three

130 monospecific and one multi-specific communities (Fig. 1), each condition comprising three

131 replicates. Only one multi-specific condition (comprising the three species) was tested as the

132 aim of this study was to examine the effect of the trait diversity on the hydraulic roughness and

133 sediment retention using contrasting traits. The multi-specific communities were composed of

134 the three species and presented a high functional diversity, with a functional divergence (FDis,

135 with a range between 0 and 1$)$ of $0.88( \pm 0.04)$ (Villéger et al. 2008).

\section{Experimental site design}

138 The plots were implanted at the bottom edge of a loamy field cultivated with winter wheat

139 located in the municipality of Drosay, Normandy, France (Fig 2.A). The soil, defined as

140 Luvisol, was characterised by $12.5 \%( \pm 0.66 \%)$ clay, $64.3 \%( \pm 0.84 \%)$ silt and $23.2 \%( \pm 0.64 \%)$

141 sand with a pH of $5.3( \pm 0.1), 2.1 \%( \pm 0.19 \%)$ of organic matter content and a crusting index of

$1421.8( \pm 0.08)$.

143 In October 2016, one year prior experiments, the plants were planted in $1 \mathrm{~m}^{2}$ plots with a density

144 of 53 young plants.m ${ }^{-2}$ (Fig. 1). The multi-specific plots were planted with the same proportion

145 of each species and the young plants were placed so young plants of the same species would

146 not be next to each other. A control condition, with no vegetation, was also tested with three

147 replicates to compare the effects of the traits between each species. Each of the 15 plots was 
148 randomly distributed along a 50m strip and $2 \mathrm{~m}$ were left between each plot to allow movement

149 and limit plant spreading in the next plot (Fig. 2.B).

\section{Hydraulic measurements}

152 A runoff simulator (Fig. 3) generating a flow at set discharges in controlled conditions was used

153 to performed the experiments in October and November 2017 (Richet et al. 2017; Kervroëdan 154 et al. 2018). The simulator was composed of three parts, two Venturi channels with ultrasound 155 probes measuring the water level in the channels $( \pm 1.26 \mathrm{~mm})$ on both ends of a channel where 156 measurements were performed. The central channel was a $5.2 \mathrm{~m}$ by $0.90 \mathrm{~m}$ stainless steel 157 channel with a $1.2 \mathrm{~m}$ bottomless part where the vegetation was located. The channel slope was 158 measured for each plot using an automatic rotating laser (Geo Fennel EL 515plus) and was 159 adjusted to $4.90 \%$ ( $\pm 0.13 \%)$, using wooden planks to ensure stability during experiments. The 160 backwater levels in front of the plots were measured using six spacers placed upstream the 161 plants. The closest spacer from the plants was $13 \mathrm{~cm}$ away, the next two were spaced by $25 \mathrm{~cm}$, 162 the forth spacer was $50 \mathrm{~cm}$ away from the third and the last two were spaced by $75 \mathrm{~cm}$. Each

163 spacer was levelled and their elevations were measured and used as elevation-known baselines 164 for the water level measurements.

165 The hydraulic parameters which were measured during the experiments were the flow discharge 166 and the water levels in the backwater area. The discharge used for the experiments was 3.6 L.s $167{ }^{1} \cdot \mathrm{m}^{-1}\left( \pm 0.06 \mathrm{~L} \cdot \mathrm{s}^{-1} \cdot \mathrm{m}^{-1}\right)$, and was continuously monitored using the upstream and downstream 168 flowmeters. The water level measurements were carried out when the upstream and 169 downstream discharges were equivalent. The perpendicular distance between the bottom of the 170 spacer and the top of the water flow was measured with an aluminium ruler. Ten water level 171 measurements were done on each spacer, every $10 \mathrm{~cm}$ along the spacer from one channel edge 
172 to the other. All the water level determinations were undertaken using clear water flows (Table $1731)$.

174 The unit stream power (USP, $\mathrm{m}_{\mathrm{s}} \mathrm{s}^{-1}$ ) was used to characterise the hydraulic roughness (Yang 175 1972; Govers 1992). Often used as a sediment transport capacity index, it defines the energy 176 dissipation of the flow, per unit of time and per unit of weight, and depends on the mean flow 177 velocity $\left(\mathrm{V}, \mathrm{m} \cdot \mathrm{s}^{-1}\right)$ and the slope $\left(\mathrm{S}, \mathrm{m} \cdot \mathrm{m}^{-1}\right)$ (Govers 1992):

$178 \quad U S P=V S$

179 The USP was calculated based on the water levels measured on the closest spacer to the 180 vegetation. The USP is negatively related to the hydraulic roughness: the lower it is, the higher 181 the hydraulic roughness will be.

182

\section{Sediment retention}

184 In June 2017, soil in the experimental site was taken off, sifted at $2 \mathrm{~mm}$ and stored until October 2017. Prior the experiments, the sediments were dried at $40^{\circ} \mathrm{C}$ for $72 \mathrm{~h}$ and stored in sealed containers. After conducting the water level measurements, sediments were integrated into the

187 flow in order to characterise the trait diversity effect on sediment retention capacity. The sediment concentration was at $11 \mathrm{~g} . \mathrm{L}^{-1}\left( \pm 0.36 \mathrm{~g} . \mathrm{L}^{-1}\right)$ at a discharge of $3.6 \mathrm{~L} . \mathrm{s}^{-1} \cdot \mathrm{m}^{-1}\left( \pm 0.09 \mathrm{~L} . \mathrm{s}^{-}\right.$

$\left.189{ }^{1} \cdot \mathrm{m}^{-1}\right)$. The sediment concentration and discharge used were chosen in order to analyse the 190 effects of traits and their divergence in plant communities on frequent erosional episodes (e.g. 191 annually) observed in the upper parts of catchments located in the European loess belt. Indeed, 192 the sediment concentration of $11 \mathrm{~g} \cdot \mathrm{l}^{-1}$ represents more than $75 \%$ of the sediment concentrations 193 measured in small catchments and in the upper parts of the catchments in the European loess 194 belt (Van Dijk et al. 1996; Cerdan et al. 2002; Le Bissonnais et al. 2004; Delmas et al. 2012; 195 Richet et al. 2017). 
196 The experiment lasted 3 min of sediment input and was followed by $30 \mathrm{sec}$ of clear water to

197 allow the last sediments to be transported. The extra $30 \mathrm{sec}$ of clear water did not significantly

198 influence the sediment particles detachment and their transport in the flow downstream the

199 vegetation (Supplementary material). In order to estimate the quantity of sediment passing 200 through the vegetation, a $250 \mathrm{ml}$ flow sample was taken every $15 \mathrm{sec}$, from the sediment input 201 to the end of the experiment. After the test run, the sediments deposited in the channel were 202 collected. All the sampled sediments were oven-dried at $105^{\circ} \mathrm{C}$ for $48 \mathrm{~h}$ and weighted. The 203 quantity of trapped sediments in the vegetation was estimated from calculation. Particle 204 granulometry was analysed using a LS 13320 Beckman Coulter particle sizing analyser for the 205 sediments deposited in the channel (upstream) and the ones downstream the vegetation.

206 The total sediment quantity downstream the vegetation was calculated using a sequential 207 calculation method, from each sample collected. The quantity trapped within the vegetation 208 ( $\left.\mathrm{S}_{\text {within }}\right)$ was estimated as followed:

$S_{\text {within }}=S_{\text {input }}-\left(S_{\text {upstream }}+S_{\text {downstream }}\right)$

210 where $S_{\text {input }}$ is the total quantity of sediments integrated into the flow, $S_{\text {upstream }}$ is the quantity 211 deposited in the channel and $S_{\text {downstream }}$ the quantity which passed through the vegetation.

212 The sediment retention capacity represented the quantity of sediments upstream and within 213 the vegetation:

$214 \quad S_{\text {retention }}=S_{\text {upstream }}+S_{\text {within }}$

\section{Leaf and stem trait measurements}

217 Six aboveground plant morphological traits (stem - density, diameter, projected area; leaf 218 density, area and specific area), known to influence the hydraulic roughness and sediment retention (Kervroëdan et al. 2018), were measured on three levels along the stem: between 0 and $5 \mathrm{~cm}, 0$ and $10 \mathrm{~cm}$ and 0 and $20 \mathrm{~cm}$. Sampling collection, samples conservation and 
analyses methods were conducted following the standardised guidelines from (Pérez-

222 Harguindeguy et al. 2013). The leaves were collected in sealed bags with moist tissue until measurements were performed and then, dried at $70^{\circ} \mathrm{C}$ for $72 \mathrm{~h}$. The traits were all measured

224 within one quadrat $(10$ by $10 \mathrm{~cm}$ ) per monospecific community plot and one quadrat per species 225 within the multi-specific community plots, due to the homogeneous plant cover within the plots. 226 The leaf density (leaves. $\mathrm{m}^{-2}$ ) was measured for each level along the stems by counting fresh 227 and dry leaves. The leaf area $\left(\mathrm{mm}^{2}\right)$ and specific area $\left(\mathrm{mm}^{2} \cdot \mathrm{mg}^{-1}\right)$ were determined using six representative leaves, scanned at 600dpi resolution, and the images were analysed using Gimp

2.8. Pseudoculms for sedges species (Cyperaceae) and tillers for grass species were counted 230 with the stems to measure the stem density $\left(\right.$ stems. $\left.\mathrm{m}^{-2}\right)$. The stem diameter $(\mathrm{mm})$ was measured 231 for each level on three representative stems and was used to calculate the projected stem area $232\left(\mathrm{~mm}^{2}\right)$, using the rectangle area formula. The aboveground biomass $(\mathrm{g})$ was estimated by collecting a $50 \times 50 \mathrm{~cm}$ quadrat in each plot and dried during $72 \mathrm{~h}$ at $70^{\circ} \mathrm{C}$. The species biomass in the multi-specific plots were separated in order to determine the biomass productivity of each 235 species.

236 Moreover, a density-weighted trait was calculated for each trait by multiplying the (1) leaf traits 237 with the leaf density and (2) stem traits with the stem density; which corresponded to the density 238 value of the traits and were dissociated from the traits with a " $\mathrm{D}$ " at the front of the trait 239 appellations.

241 Characterisation of the trait diversity effects on the hydraulic roughness and sediment

\section{2 retention}

243 All multi-specific plots were planted with an equal abundance of each species, although these 244 abundances changed through the year to experiments. The abundance (\%) of each species was 245 estimated for each multi-specific plot. 
The community-weighted traits (CWT) were calculated for each trait in the multi-specific plots

247 by weighting each trait with the species abundance (Díaz et al. 2007; Violle et al. 2007):

$248 \quad C W T_{i}=\sum_{k=1}^{n_{i}} A_{k, i} T_{k, i}$

249 with $C W T_{i}$ being the community-weighted value of the trait in the community $\mathrm{i}, \mathrm{A}_{\mathrm{k}, \mathrm{i}}$ and $\mathrm{T}_{\mathrm{k}, \mathrm{i}}$ 250 being, respectively, the relative abundance and the trait value of the species $\mathrm{k}$ in the community $251 \quad i$ and $n_{i}$ being the number of species in the community $i$.

252 The complementarity effect on the traits was determined using the land equivalent ratio (LER); 253 which is the relative area required for monoculture to grow with the same productivity as when 254 the species are in mixture (Mead and Willey 1980). The LER was calculated for each species 255 trait in the multi-specific plots as follows:

$L E R=p L E R_{A}+p L E R_{B}=\frac{T_{A, \text { multi-specific }}}{T_{A, \text { monospecific }}}+\frac{T_{B, \text { multi-specific }}}{T_{B, \text { monospecific }}}$

with pLER $_{\mathrm{A}}$ and pLER $_{\mathrm{B}}$ being the partial LERs for the species $\mathrm{A}$ and $\mathrm{B} ; \mathrm{T}_{\mathrm{A} \text {,multi-specific and }}$ $T_{B}$,multi-specific being the trait values of the species $A$ and $B$ in the multi-specific conditions; and

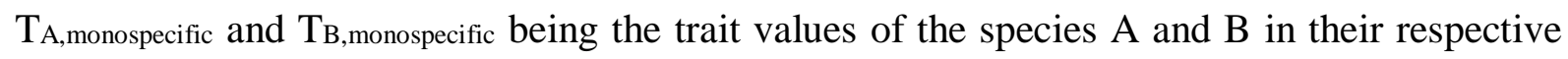
monospecific conditions. If LER > 1, the multi-specific condition presents an advantage for the trait value compared when the species is in monospecific condition. In the contrary, if LER < 1 , there is a detrimental effect on the trait of the multi-specific condition compare to the monospecific. The pLER allows to indicate competitive effects between the species, within the multi-specific condition, using pLER $<(1 / n)$ or pLER $>(1 / n)$ as an indices, with $n$ the species number (Mead and Willey 1980; Hector 1998; Darch et al. 2018).

\section{Data analyses}

268 Comparison analyses highlighting the differences between the community-weighted traits of each tested condition were carried out using ANOVA and Tukey post-hoc tests on the community- weighted trait values of the three monospecific and the multi-specific conditions. 
271 The effects of each vegetated condition in comparison to the control condition on the unit

272 stream power and sediment retention were tested using Kruskal-Wallis and Dunn's tests.

273 Comparative analyses using Mann-Whitney tests were performed on the USP and the sediments

274 (quantities and granulometries) data, gathered under "monospecific" and "multi-specific" 275 categories, in order to identify if there was a complementarity or a selection effect of the trait 276 diversity on these processes.

277 To identify differences between the communities, ANOVA and Kruskal-Wallis analyses were 278 computed accordingly to the normality of the data on the USP, the sediments (quantities and 279 granulometries) and the LER data. The analyses' respective post-hoc tests Tukey and Dunn's 280 were also performed. As the aim of the analyses was to understand the effects of the trait 281 diversity on the tested variables, control data were excluded. All the statistical analyses were 282 carried out using the "Stats" and "dunn.test" packages in the statistical software R (version 283 3.3.2).

\section{Results}

287 The traits in the monospecific conditions and their effects on the unit stream power and 288 sediment retention

289 The comparison analyses of the trait values between each monospecific condition emphasised 290 the contrasting leaf densities found between each species (Table 2). C. pendula presented 291 significantly lower CW density-weighted projected stem area and CW density-weighted stem 292 diameter with $F$. arundinacea and no difference with $T$. vulgare for the cited traits. The CW 293 density-weighted leaf area of $C$. pendula was not different with $F$. arundinacea and larger than $294 T$. vulgare's. The CW leaf area of $C$. pendula presented a significant difference with the leaf 295 area of $F$. arundinacea and $T$. vulgare. Regarding the effects on the unit stream power and 
sediment retention, the analyses showed no significant differences between the control and $T$.

297 vulgare, while $C$. pendula and $F$. arundinacea had significant lower unit stream power and

higher quantity of retained sediments than the control. C. pendula had higher hydraulic roughness (thus, a lower unit stream power) and quantity of sediments retained than T. vulgare.

Effects of the trait diversity on the community-weighted traits involved in the increase of the hydraulic roughness and sediment retention

The comparison analyses between the $\mathrm{CW}$ traits in the monospecific and the multi-specific conditions showed (1) a higher CW leaf area in the $C$. pendula monoculture than in the multispecific condition; (2) more important $\mathrm{CW}$ leaf densities $(0-5 \mathrm{~cm}, 0-10 \mathrm{~cm}$ and $0-20 \mathrm{~cm})$ in the multi-specific condition than in the T. vulgare monoculture; and (3) more important $\mathrm{CW}$ density-weighted leaf areas densities $(0-5 \mathrm{~cm}, 0-10 \mathrm{~cm}$ and $0-20 \mathrm{~cm})$ in the multi-specific condition than in the T. vulgare monoculture (Table 2). Regarding the LER, the biomass productivity and the leaf density $(0-5 \mathrm{~cm} ; 0-10 \mathrm{~cm}$ and $0-20 \mathrm{~cm})$ were higher in the multispecific communities, with a LER $>1$ (Table 3$)$. The density-weighted projected stem area $(0$ $-5 \mathrm{~cm})$ and density-weighted stem diameter $(0-5 \mathrm{~cm})$ did not show differences between monospecific and multi-specific communities, with a LER $=1$. Higher traits values were found for F. arundinacea, $C$. pendula (only the leaf area, the specific leaf area and the leaf density (0 $-5 \mathrm{~cm}, 0-10 \mathrm{~cm}$ and $0-20 \mathrm{~cm}$ ) ) and $T$. vulgare (only the leaf density $(0-5 \mathrm{~cm}, 0-10 \mathrm{~cm}$ and $0-20 \mathrm{~cm})$ ) in the multi-specific communities, with partial LER $>0.33$. The biomass productivity was favoured in the multi-specific condition for $F$. arundinacea and T. vulgare (LER > 0.33) but was not higher for C. pendula.

Trait diversity effects on the unit stream power, the sediment retention and the quantity of each size category of sediment particle retained 
321 When averaging the three monospecific conditions under the category "monospecific", the comparison analysis of the unit steam power showed no significant difference between the monospecific and the multi-specific conditions. There were no differences between the mean

324 of the monospecific and the multi-specific conditions for the sediment quantities upstream, 325 within and downstream the vegetation. Similar results were also found for the sediment particle 326 sizes.

327 The comparison analysis between each condition regarding the unit stream power showed that T. vulgare had a significantly lower hydraulic roughness than $C$. pendula and the multi-specific condition (Fig. 4). Regarding the sediment retention (quantities upstream and within the 330 vegetation), the results showed differences between the multi-specific condition and T. vulgare, 331 which was also different from $C$. pendula (Fig. 5.A). When focussing on the size categories of 332 the sediment particles retained by the vegetation, the multi-specific condition was not different 333 from the monospecific conditions for each category; while $C$. pendula had a bigger amount of 334 each size category than T. vulgare (Fig. 5.A). F. arundinacea did not present any difference 335 with any of the other conditions for each sediment size fraction (Fig. 5.A). The quantity of 336 particles between 100 and $2000 \mu \mathrm{m}$ showed no difference between each condition. The quantity 337 of sediments downstream the vegetation was significantly higher for $T$. vulgare than for $C$. 338 pendula and the multi-specific conditions (Fig. 5.B). The quantity of particles between 50 and $339100 \mu \mathrm{m}$ and between 100 and $2000 \mu \mathrm{m}$ was smaller for the multi-specific and $C$. pendula than 340 for T. vulgare (Fig. 5.B).

\section{Discussion}

344 The aboveground traits of a vegetation constitute the main drivers for generating hydraulic 345 roughness and sediment retention in an herbaceous community. The density-weighted leaf area 
346 (product of the leaf area and the leaf density) influenced the hydraulic roughness and the 347 sediment retention in the present study, highlighted by the lower values of this trait in the $T$. 348 vulgare condition which showed the lowest hydraulic roughness and sediment retention. The 349 density-weighted leaf area has been emphasised as a main trait influencing the hydraulic 350 roughness, especially when combined with an important density-weighted stem diameter in 351 herbaceous vegetation (Kervroëdan et al. 2018). This strong relationship between the density352 weighted leaf area and the hydraulic roughness and sediment retention strengthen the hypothesis observed in the literature that vegetation composed of species with a good trade-off between leaf density and leaf area (i.e. presenting an important density of long leaves), such as graminoid species, would present a greater impact on the hydraulic roughness and a higher 356 efficiency to retain sediments (Morgan 2004; Isselin-Nondedeu and Bédécarrats 2007). Better 357 effects of the traits of graminoid species were also highlighted in the present study with a higher 358 hydraulic roughness and sediment retention for C. pendula and F. arundinacea (with $84 \%$ and $76.2 \%$ of the sediments retained, respectively) than T. vulgare (with $69.7 \%$ of the sediments 360 being retained). The hypothesis that vegetation composed of traits inducing a high efficiency 361 in sediment retention would present a wider diversity of sediment particle sizes was also 362 emphasised in the graminoid conditions due to their higher density-weighted leaf area, 363 especially for $C$. pendula. The effects of herbaceous vegetation, notably graminoid species, on

364 sediment retention regarding the particle size fractions have been studied over the past decades, 365 especially in the concern of pollutants dispersion with the finer particles (Meyer et al. 1995; 366 Syversen and Borch 2005; Liu et al. 2008; Lambrechts et al. 2014). It has been shown that the 367 coarser particles tend to deposit upstream the vegetation while finer one deposit within or pass 368 through the vegetation. In our study, most of the particles coarser than $50 \mu \mathrm{m}$ were retained by 369 all the conditions tested with vegetation while there was a decrease of the retention efficiency 370 for finer particle sizes, which is the same pattern found in the literature (Meyer et al. 1995; 
Syversen and Borch 2005). This was especially observed for T. vulgare (for particles $<2 \mu \mathrm{m}$ ) which presented significantly lower density-weighted leaf areas and thus, a lower hydraulic roughness.

The effects of the trait diversity on runoff and soil erosion processes have been emphasised, with contentious results (Pohl et al. 2009; Martin et al. 2010; Erktan et al. 2013; Berendse et al. 2015; Zhu et al.2015). In this study, we focussed on the effects of the aggregation of contrasting traits involved in the increase of the hydraulic roughness and sediment retention which are negatively associated. We hypothesised that the aggregation of these contrasting traits would present a complementary effect on the hydraulic roughness and sediment retention, as well as would induce a greater quantity of sediment particle sizes retained by the vegetation. However, while the trait diversity should have led to a greater hydraulic roughness, the results showed no significant increase in hydraulic roughness nor sediment retention for the multi-specific communities. Indeed, the complementarity hypothesis stipulates that the trait divergence in plant communities influences ecosystem processes and leads to a more complete space and resources use (Loreau and Hector 2001). This absence of complementarity effects could not be explained by the biomass productivity of the plant community, as for a greater productivity in the multi-specific condition there was no greater effects on the hydraulic roughness nor on the sediment retention, emphasising that biomass productivity was not a major factor to increase sediment retention. The absence of differences between the mean of the monospecific and the multi-specific communities indicated a dominant effect of the traits of specific species in the community on runoff and sediment transport capacity (Grime 1998; Lorentzen et al. 2008). This dominance effect would be led by the traits of $F$. arundinacea and $C$. pendula and more specifically by their $\mathrm{CW}$ density-weighted leaf area, emphasising the greater effect of graminoid species. These results on dominance effects of the community-weighted traits are not in accordance with the complementarity effects of plant species diversity found on runoff, 
soil erosion and soil aggregation capacity in other studies (Pohl et al. 2009; Martin et al. 2010;

Zhang et al. 2015). However, these studies focussed on non-herbaceous spontaneous plant communities of mountainous or semi-arid environments, which usually comprise different (e.g. more intense) runoff and erosion episodes and adapted spontaneous vegetation towards these processes (Guerrero-Campo and Montserrat-Martí 2000). These opposing results could be explained by idiosyncratic effects (i.e. contrasting effects of the plant species diversity), impacted by species-traits and soil-plant interactions (Loreau 2000). The idiosyncratic effects could be influenced by the species combination and structure in the community (Parsons et al. 1996; Loreau 2000; Erktan et al. 2013), which is consistent with results showing the decrease of soil erosion resistance with the disappearance of species in the community (Berendse et al. 2015). Moreover, an increasing proportion of species with larger stems diameters would create preferential flow paths and further runoff intensity, which would impact the effect of the trait diversity on the hydraulic roughness and sediment retention (Parsons et al. 1996; Erktan et al. 2013). This hypothesis is consistent with our results, showing the negative influence on the unit stream power of the traits of $T$. vulgare by reducing the hydraulic roughness and sediment retention within the multi-specific conditions, due to its larger stem diameters than the two 412 other tested species. Negative effects of species with large stem diameters were also highlighted 413 in the literature, highlighting their influence over the water path within the vegetation and the 414 overall neutral effect of trait diversity (Erktan et al. 2013). This postulate coincides with the 415 traits' effects found regarding the size of the sediment particles upstream the vegetation, as the 416 preferential flow paths induced by the presence of larger stems would accelerate the flow 417 velocity at the path's scale and further the transport of sediment particles. Indeed, while a wider 418 variety of sediment particle sizes was expected within the retained sediments by the multi419 specific condition, there was no significant difference between the monospecific and the multi420 specific conditions for each particle size category. To understand the idiosyncratic effects on 
hydraulic roughness and sediment retention, perspective is to examine the effects of trait

422 diversity on hydraulic roughness and sediment retention by using a wide gradient of functional

423 diversity, with a variation in the abundance of the traits involved in hydraulic roughness

424 increase, to unravel the relationship between trait diversity and sediment retention.

\section{Conclusions}

428 This trait-based ecohydrology study allowed to further the understanding of the effect of trait diversity on runoff and soil erosion processes. The results emphasised that there was not a better effect of trait diversity on the hydraulic roughness and sediment retention, as well as on the quantity of sediment fractions. The absence of negative effects on sediment retention suggests

432 that multi-specific communities can be used to mitigate soil erosion and can be recommended 433 because plant species and functional diversity could offer other ecosystem processes and services. Perspective is to examine the effects of functional diversity on several main ecosystem processes in herbaceous hedges created to mitigate soil erosion, to design multi-functional ecosystems.

\section{Authors' Contributions}

440 Léa Kervroëdan, Michel-Pierre Faucon and Romain Armand conceived the objectives and 441 designed the methodology; Léa Kervroëdan and Mathieu Saunier collected the data; Léa

442 Kervroëdan analysed the data; Léa Kervroëdan and Michel-Pierre Faucon led the writing of the 443 manuscript. All authors contributed critically to the drafts and gave final approval for 444 publication. 


\section{Acknowledgements}

448 The authors thank the funders of this study: Agence de l'Eau Seine-Normandie (Seine-

Normandie Catchment Agency), Région Normandie (Normandy council) and ANRT (National

Association for Technological Research). Special acknowledgements are given to Dr. Yves le

Bissonnais and Dr. Freddy Rey for their scientific comments on the methods of our study and

to Dr. Jean-François Ouvry and Mr Jean-Baptiste Richet for their insightful comments and technical advices.

\section{References}

457

458

459

460

461

462

463

464

465

466

Akram S, Yu B, Ghadiri H, et al (2014) The links between water profile, net deposition and erosion in the design and performance of stiff grass hedges. Journal of Hydrology 510:472-479. doi: 10.1016/j.jhydrol.2014.01.001

Bautista S, Mayor ÁG, Bourakhouadar J, Bellot J (2007) Plant Spatial Pattern Predicts Hillslope Runoff and Erosion in a Semiarid Mediterranean Landscape. Ecosystems 10:987-998. doi: 10.1007/s10021-007-9074-3

Berendse F, van Ruijven J, Jongejans E, Keesstra S (2015) Loss of plant species diversity reduces soil erosion resistance. Ecosystems 18:881-888. doi: 10.1007/s10021-0159869-6

Boardman J, Poesen J (eds) (2006) Soil Erosion in Europe. John Wiley \& Sons, Ltd

Burylo M, Rey F, Bochet E, Dutoit T (2012) Plant functional traits and species ability for sediment retention during concentrated flow erosion. Plant and Soil 353:135-144. doi: $10.1007 / \mathrm{s} 11104-011-1017-2$

Cerdan O, Bissonnais YL, Souchère V, et al (2002) Sediment concentration in interrill flow: interactions between soil surface conditions, vegetation and rainfall: SEDIMENT CONCENTRATION IN INTERRILL FLOW. Earth Surface Processes and Landforms 27:193-205. doi: 10.1002/esp.314

Darch T, Giles CD, Blackwell MSA, et al (2018) Inter- and intra-species intercropping of barley cultivars and legume species, as affected by soil phosphorus availability. Plant and Soil 427:125-138. doi: 10.1007/s11104-017-3365-z 
Delmas M, Pak LT, Cerdan O, et al (2012) Erosion and sediment budget across scale: A case study in a catchment of the European loess belt. Journal of Hydrology 420-421:255263. doi: 10.1016/j.jhydrol.2011.12.008

Díaz S, Lavorel S, Chapin FS, et al (2007) Functional Diversity - at the Crossroads between Ecosystem Functioning and Environmental Filters. In: Canadell JG, Pataki DE, Pitelka LF (eds) Terrestrial Ecosystems in a Changing World. Springer Berlin Heidelberg, Berlin, Heidelberg, pp 81-91

Dillaha TA, Reneau RB, Mostaghimi S, Lee D (1989) Vegetative filter strips for agricultural nonpoint source pollution control. Transactions of the ASAE 32:513-0519

Erktan A, Cécillon L, Roose E, et al (2013) Morphological diversity of plant barriers does not increase sediment retention in eroded marly gullies under ecological restoration. Plant and Soil 370:653-669. doi: 10.1007/s11104-013-1738-5

Fargione J, Tilman D, Dybzinski R, et al (2007) From selection to complementarity: shifts in the causes of biodiversity-productivity relationships in a long-term biodiversity experiment. Proceedings of the Royal Society B: Biological Sciences 274:871-876. doi: 10.1098/rspb.2006.0351

Garnier E, Navas M-L, Grigulis K (2016) Plant Functional Diversity: Organism Traits, Community Structure, and Ecosystem Properties. Oxford University Press

Govers G (1992) Relationship between discharge, velocity and flow area for rills eroding loose, non-layered materials. Earth surface processes and landforms 17:515-528

Grime JP (1998) Benefits of plant diversity to ecosystems: immediate, filter and founder effects. Journal of ecology 86:902-910. doi: 10.1046/j.1365-2745.1998.00306.x

Guerrero-Campo J, Montserrat-Martí G (2000) Effects of soil erosion on the floristic composition of plant communities on marl in northeast Spain. Journal of Vegetation Science 11:329-336

Gyssels G, Poesen J, Bochet E, Li Y (2005) Impact of plant roots on the resistance of soils to erosion by water: A review. Progress in Physical Geography 29:189-217. doi: 10.1191/0309133305pp443ra

Haan CT, Barfield BJ, Hayes JC (1994) Design Hydrology and Sedimentology for Small Catchments. Academic Press

Hector A (1998) The Effect of Diversity on Productivity: Detecting the Role of Species Complementarity. Oikos 82:597. doi: 10.2307/3546380

Hou J, Wang H, Fu B, et al (2016) Effects of plant diversity on soil erosion for different vegetation patterns. CATENA 147:632-637. doi: 10.1016/j.catena.2016.08.019

Hussein J, Yu B, Ghadiri H, Rose C (2007) Prediction of surface flow hydrology and sediment retention upslope of a vetiver buffer strip. Journal of Hydrology 338:261-272 
Isselin-Nondedeu F, Bédécarrats A (2007) Influence of alpine plants growing on steep slopes on sediment trapping and transport by runoff. Catena 71:330-339. doi: 10.1016/j.catena.2007.02.001

Kervroëdan L, Armand R, Saunier M, et al (2018) Plant functional trait effects on runoff to design herbaceous hedges for soil erosion control. Ecological Engineering 118:143151. doi: 10.1016/j.ecoleng.2018.04.024

Lambinon J, Delvosalle L, Duvigneaud J (2012) Nouvelle flore de la Belgique, du G.-D. de Luxembourg, du nord de la France et des régions voisines, 6th edn.

Lambrechts T, de Braekeleer C, Fautsch V, et al (2014) Can vegetative filter strips efficiently trap trace elements during water erosion events? A flume experiment with contaminated sediments. Ecological Engineering 68:60-64. doi: 10.1016/j.ecoleng.2014.03.092

Le Bissonnais Y, Lecomte V, Cerdan O (2004) Grass strip effects on runoff and soil loss. Agronomie 24:129-136

Liu X, Zhang X, Zhang M (2008) Major Factors Influencing the Efficacy of Vegetated Buffers on Sediment Trapping: A Review and Analysis. Journal of Environment Quality 37:1667. doi: $10.2134 /$ jeq2007.0437

Liu Y-J, Hu J-M, Wang T-W, et al (2016) Effects of vegetation cover and road-concentrated flow on hillslope erosion in rainfall and scouring simulation tests in the Three Gorges Reservoir Area, China. CATENA 136:108-117. doi: 10.1016/j.catena.2015.06.006

Loreau M (2000) Biodiversity and ecosystem functioning: recent theoretical advances. Oikos 91:3-17. doi: 10.1034/j.1600-0706.2000.910101.x

Loreau M, Hector A (2001) Partitioning selection and complementarity in biodiversity experiments. Nature 412:72-76. doi: 10.1038/35083573

Lorentzen S, Roscher C, Schumacher J, et al (2008) Species richness and identity affect the use of aboveground space in experimental grasslands. Perspectives in Plant Ecology, Evolution and Systematics 10:73-87. doi: 10.1016/j.ppees.2007.12.001

Martin C, Pohl M, Alewell C, et al (2010) Interrill erosion at disturbed alpine sites: Effects of plant functional diversity and vegetation cover. Basic and Applied Ecology 11:619626. doi: 10.1016/j.baae.2010.04.006

Mead R, Willey RW (1980) The Concept of a 'Land Equivalent Ratio' and Advantages in Yields from Intercropping. Experimental Agriculture 16:217-228. doi: $10.1017 / \mathrm{S} 0014479700010978$

Mekonnen M, Keesstra SD, Ritsema CJ, et al (2016) Sediment trapping with indigenous grass species showing differences in plant traits in northwest Ethiopia. Catena 147:755-763. doi: 10.1016/j.catena.2016.08.036

Meyer LD, Dabney SM, Harmon WC (1995) Sediment-trapping effectiveness of stiff-grass hedges. ASAE 38:809-815 
Morgan RPC (2004) Vegetative-Based Technologies for Erosion Control. In: Stokes A, Spanos I, Norris JE, Cammeraat E (eds) Eco- and Ground Bio-Engineering: The Use of Vegetation to Improve Slope Stability. Springer, Dordrecht, The Netherlands, pp 265272

Naeem S, Thompson LJ, Lawler SP, et al (1994) Declining biodiversity can alter the performance of ecosystems. Nature 368:734-737. doi: 10.1038/368734a0

Parsons AJ, Abrahams AD, Wainwright J (1996) Responses of interrill runoff and erosion rates to vegetation change in southern Arizona. Geomorphology 14:311-317. doi: 10.1016/0169-555X(95)00044-6

Pérez-Harguindeguy N, Díaz S, Garnier E, et al (2013) New handbook for standardised measurement of plant functional traits worldwide. Australian Journal of Botany 61:167234. doi: 10.1071/BT12225

Pohl M, Alig D, Körner C, Rixen C (2009) Higher plant diversity enhances soil stability in disturbed alpine ecosystems. Plant and Soil 324:91-102. doi: 10.1007/s11104-0099906-3

Richet J-B, Ouvry J-F, Saunier M (2017) The role of vegetative barriers such as fascines and dense shrub hedges in catchment management to reduce runoff and erosion effects: Experimental evidence of efficiency, and conditions of use. Ecological Engineering 103:455-469. doi: 10.1016/j.ecoleng.2016.08.008

Stokes A, Douglas GB, Fourcaud T, et al (2014) Ecological mitigation of hillslope instability: ten key issues facing researchers and practitioners. Plant and Soil 377:1-23. doi: $10.1007 / \mathrm{s} 11104-014-2044-6$

Styczen ME, Morgan RPC (1995) Engineering properties of vegetation. In: Morgan RPC, Rickson RJ (eds) Slope Stabilization and Erosion Control: A Bioengineering Approach. E \& FN SPON, London, pp 4-60

Syversen N, Borch H (2005) Retention of soil particle fractions and phosphorus in cold-climate buffer zones. Ecological Engineering 25:382-394. doi: 10.1016/j.ecoleng.2005.06.005

Tilman D (2001a) Diversity and Productivity in a Long-Term Grassland Experiment. Science 294:843-845. doi: 10.1126/science.1060391

Tilman D (2001b) Functional Diversity. In: Levin SA (ed) Encyclopedia of Biodiversity. Elsevier, New York, pp 109-120

Van Dijk PM, Kwaad FJPM, Klapwijk M (1996) Retention of water and sediment by grass strips. Hydrological Processes 10:1069-1080. doi: 10.1002/(SICI)10991085(199608)10:8<1069::AID-HYP412>3.0.CO;2-4

Villéger S, Mason NW, Mouillot D (2008) New multidimensional functional diversity indices for a multifaceted framework in functional ecology. Ecology 89:2290-2301

Violle C, Navas M-L, Vile D, et al (2007) Let the concept of trait be functional! Oikos 116:882892. doi: 10.1111/j.2007.0030-1299.15559.x 
Yang CT (1972) Unit stream power and sediment transport. ASCE Journal of the Hydraulics 589 Division 98:1805-1826

590 Zhang L, Wang J, Bai Z, Lv C (2015) Effects of vegetation on runoff and soil erosion on reclaimed land in an opencast coal-mine dump in a loess area. CATENA 128:44-53. doi: 10.1016/j.catena.2015.01.016

Zhu H, Fu B, Wang S, et al (2015) Reducing soil erosion by improving community functional diversity in semi-arid grasslands. Journal of Applied Ecology 52:1063-1072. doi: $10.1111 / 1365-2664.12442$ 
597 Fig. 1 Experimental plots with three monospecific and one multi-specific communities.

598 The photos from October 2016 were taken just after the plantation and the ones from September

5992017 were taken a month prior experiment.

600

601 Fig. 2 Experimental site. A - Location of the experimental site in Drosay, France and B

$602-$ Arrangement of the plots within the experimental area.

603

604

Fig. 3 Runoff simulator used for the experiments.

605

606

Fig. 4 Differences between each community for the unit stream power. The bars represent

607 the mean \pm standard error. The letters represent the significant differences between each

608 condition according to Tukey post-hoc tests. The significance level "ns" means not significant.

609

610 Fig. 5 Differences between each community for (A) the sediment quantities for each

611 particle size category upstream the vegetation and (B) the sediment quantities for each

612 particle size category downstream the vegetation. The error bars represent the mean \pm

613 standard error. The letters represent the significant differences between each condition

614 according to the Tukey post-hoc tests, for each sediment size fraction. The significance level

615 "ns" means not significant. The uppercase letters in bold represent the differences between each

616 condition in the overall sediment quantities, according to the Tukey post-hoc tests. 